\title{
BAHAYA LATEN INFEKSI GONORE DAN KLAMIDIA DI ASIA SELATAN \& ASIA TENGGARA, DI INDONESIA DAN KOTA MANADO
}

\author{
Pirade, $A$
}

Fakultas Kedokteran Universitas Sam Ratulangi Manado

(aron_pirade@yahoo.com)

\section{ABSTRAK}

Prevalensi STI (Sexual Transmitted Infection) khususnya Gonore dan Klamidia di dunia menempati urutan tertinggi. Wilayah Asia Selatan dan Asia Timur-Selatan (juga disebut Asia Tenggara) adalah wilayah dengan prevalensi Gonore dan Klamidia terbesar. Prevalensi Gonore di tahun 1995 dan 1999 yaitu 29.11 dan 27.2 juta penduduk wilayah Asia Selatan dan Asia Tenggara. Klamidia, di tahun 1995 dan tahun 1999 yaitu 40.48 dan 42.89 juta penduduk wilayah Asia Selatan dan Asia Tenggara. Di Indonesia sendiri, pada 11 area penelitian menunjukkan bahwa prevalensi Gonore dalam wilayah Indonesia menunjukkan rata-rata prosentasenya $20 \%-40 \%$ dari keseluruhan STI pada wanita beresiko tinggi terkena STI. Sedangkan infeksi oleh Klamidia prosentasenya 15\%45\% dari keseluruhan STI pada wanita beresiko tinggi terkena penyakit kelamin. Prosentase Gonore dan Klamidia di Kota Manado rata-rata 15-30\%. Tingginya prevalensi infeksi Gonore dan Klamidia di Asia Tenggara, ternyata diikuti juga dengan tingginya perkembangan infeksi Gonore dan Klamidia di Indonesia dan Kota Manado.

\section{Definisi}

STI (Sexual Transmitted Infection) dalam bahasa Indonesia disebut IMS (Infeksi Menular Seksual) adalah penyakit seksual dengan penyebabnya berbagai infeksi yang ditularkan terutama secara genito-genital dan dapat pula ano-genital, oro-genital, serta kontak langsung dengan alat-alat penderita. ${ }^{1}$

STI adalah satu diantara penyakit infeksi terbesar di dunia. WHO (2001) mencatat ada 1 dintara 26 orang di dunia yang sedang mengidap STI. Di Asia Selatan dan Asia Tenggara sendiri tercatat 1 diantara 20 orang sedang terinfeksi STI. Dan diperkirakan ada 340 juta penduduk dunia akan terkena STI. Karena belum adanya organisasi dunia resmi yang meneliti penyakit ini, jadi deteksi penyakit ini belum dilakukan secara menyeluruh dan periodik sehingga diperoleh data STI yang akurat. $^{4}$

\section{Faktor Penyebab Meningkatnya Insiden IMS}

\section{Beberapa faktor tersebut antara lain ${ }^{12}$ :}

1 Perubahan demografi yang luar biasa yang meliputi .

a.Peledakan jumlah penduduk

b.Mobilitas yang tinggi. termasuk antar bangsa

c.Meningkatnya keadaan sosial ekonomi

d.Meningkatnya praktek pelacuran baik yang terang-terangan maupun yang terselubung.
2 Perubahan perilaku. terutama yang menyangkut aspek moral dan agama, seperti kehidupan seks bebas.

3 Kebebasan kehidupan pribadi yang makin besar.

\section{Trachomatis}

Merupakan penyebab terbesar (50\%) dari UNS (Uretritis Nonspesifik). 1 dikenal dengan nama Miyagawanella, Bedsonia.

\section{Morfologi}

Bakteri gram negatif. Ukuran 0,2-1,5 mikron, bentuk sferis, tidak bergerak, merupakan parasit intra-obligat. $^{3}$

\section{Struktur}

Dinding sel (kapsul) serupa dengan kuman gram negatif mengandung peptidoglikan, fosfolipid, membrana sitoplasma, sitoplasma, inti sel. ${ }^{3}$

\section{Gejala klinis}

Pria, riwayat kontak seksual 1-3minggu, duh tubuh seropurulen namun terkadang tanpa duh tubuh sehingga memerlukan pemeriksaan laboratorium. Wanita, asimtomatik, sebagian kecil mengeluh disuria ringan, duh tubuh seropurulen, dispareuni, nyeri di area pelvis. ${ }^{3}$

\section{N. GONORRHOEAE}

Merupakan penyebab penyakit gonore atau dikenal di masyarakat dengan kencing nanah. $^{1}$ 


\section{Morfologi}

N. gonorrhoeae atau gonokokus merupakan kuman bentuk ginjal berdiameter 0,8 mikron. Diplokokus, tidak bergerak secara aktif, dan tidak berspora. Strain virulen, terutama mempunyai pili di permukaannya. Gonokokus mempunyai beberapa jenis plasmid, contohnya pembawa gen resisten pada pembuatan beta-laktamase dan penisilinase. $^{2}$

\section{Struktur}

Berturut-turut dari luar ke dalam ada kapsul, membrana luar (pitus, peptidoglikan, protein I dan II, lipopolisakarida), membrana sitoplasma, sitoplasma dan inti sel. ${ }^{2}$

\section{Gejala klinis}

Pria, riwayat kontak seksual 1 minggu, keluar pus saat miksi, disuria, kadang demam, kadang asimtomatik. Wanita, dominan asimtomatik, bila disertai gejala yaitu disuria, poliuria, keluar pus dari vagina saat miksi, demam, nyeri di abdomen.

\section{METODE}

\section{Rancangan Penelitian}

Penelitian ini merupakan penelitian deskriptif dengan merangkum data yang diperoleh dari berbagai kepustakaan berupa text book, jurnal, artikel kesehatan yang berkaitan dengan pembahasan. Kemudian dianalisa guna mendapat kesimpulan akhir.

\section{Pengolahan data}

Data karya ilmiah ini dikumpulkan dari berbagai textbook, jurnal, artikel kesehatan yang berkaitan dengan pembahasan. Kemudian seluruh data yang terkumpul diolah, dirangkum, dan disajikan dalam bentuk grafik, tabel, serta gambar.

\section{Waktu dan tempat}

Tempat penyusunan karya ilmiah dilaksanakan di rumah dan perpustakaan Fakultas Kedokteran Unsrat. Waktu pelaksanaan 28 Desember 2011 11 Januari 2012.

\section{Alur Penelitian}

Alur penelitiannya didasarkan pada latar belakang kemudian dicarilah data primer (jurnal-jurnal) dan data sekunder (text book) kemudian di lakukan analisis dan sintesis sehingga didapatlah suatu kesimpulan dari penelitian.

\section{Patogenesis}

Infeksi primer terjadi epitel silindris dari uretra, duktus periuretralis, dan beberapa kelenjar disekitarnya dengan menempelkan pili pada permukaan sel epitel atau mukosa. Kuman yang mencapai jaringan ikat dibawah jaringan epitel menimbulkan reaksi radang berupa infiltrasi leukosit polimorfonuklear yang menimbulkan adanya eksudat dan bila menyumbat saluran atau kelenjar akan terbentuk kista retensi dan abses. Penyebaran ke organ lain sering lewat saluran getah bening. $^{2}$

\section{HASIL}

Data statistik menyangkut STI, infeksi gonore serta infeksi klamidia di seluruh dunia diperoleh dari WHO yang diterbitkan tahun 2001.

\section{Statistik STI di dunia}

Data jumlah penduduk dunia di tahun 1999. Jika dibandingkan antara beberapa wilayah di dunia tentang prevalensi STI di wilayah-wilayah tersebut, maka wilayah Asia Selatan dan Asia Timur-Selatan (Asia Tenggara) merupakan wilayah yang memiliki jumlah penduduk tertinggi yang terkena STI. 48 juta dari 995 juta penduduk menderita STI. Ada satu wilayah yang tingkat STInya juga tinggi yaitu wilayah Afrika Sub-Sahara. Penduduk wilayah Afrika Sub-Sahara juga punya prevalensi STI yang tinggi. 32 juta dari 269 juta penduduknya merupakan penderita STI. Statistik penduduk dunia memang menunjukkan penduduk di wilayah Asia Selatan dan Asia tenggara jauh lebih tinggi dibandingkan dengan wilayah lain, salah satu alasannya karena 2 dari 4 negara dengan penduduk terbanyak di dunia menempati wilayah ini. Akan tetapi tingginya jumlah penduduk ini ternyata diikuti dengan tingginya jumlah penduduk penderita STI. Namun, faktor wilayah dengan penduduk dunia terbanyak rasanya bukan satu-satunya indikator karena meski di wilayah Asia Timur dan Pasifik punya penduduk dunia yang tinggi tapi prevalensi penduduk untuk menderita STI sangat rendah. Untuk keterangan lebih lanjut dapat dilihat dari grafik 1 di bawah ini. 


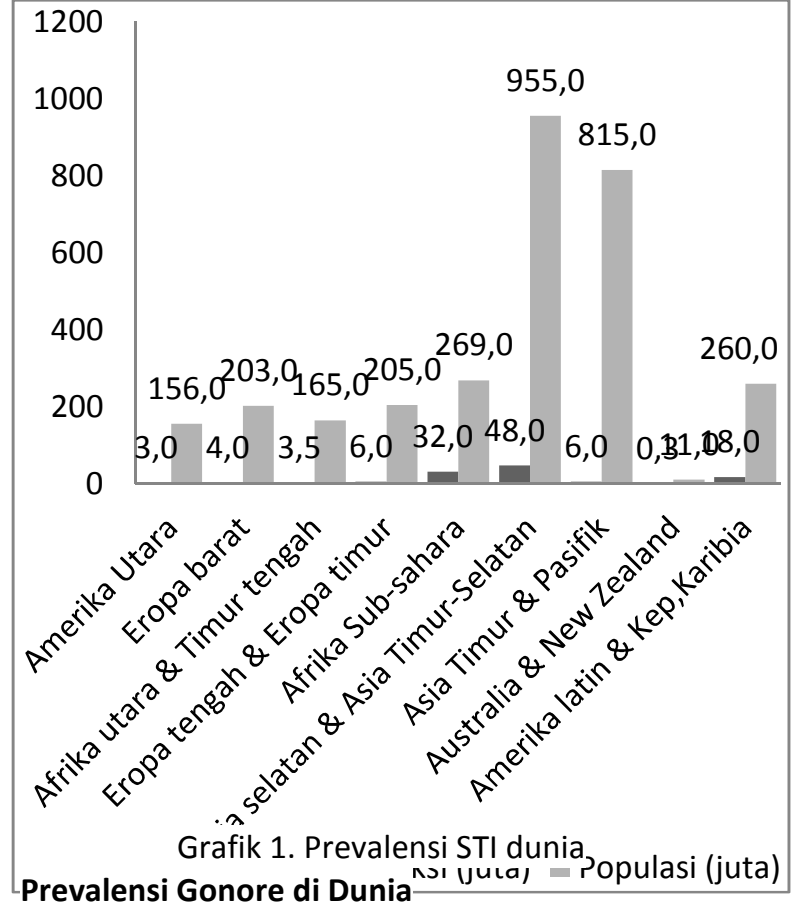

Dari data grafik 2 di bawah ini diamati bahwa prevalensi infeksi gonore di dunia pada tahun 1995 berjumlah 62.14 juta penduduk dunia. 4 tahun kemudian, di tahun 1999 prevalensi penduduk yang menderita infeksi gonore berjumlah 62.34 juta dari 120.8 juta penduduk yang menderita STI, bila diprosentasekan maka $51.6 \%$ penderita STI disebabkan oleh infeksi kuman N.gonorrhoeae. Baik ditahun 1995 dan 1999, wilayah Asia Selatan dan Asia Tenggara merupakan wilayah dengan infeksi gonore tertinggi dengan 29.11 juta dan 27.2 juta. khusus di tahun 1999, ada $2.84 \%$ dari 955 juta penduduk di wilayah Asia Selatan dan Asia Tenggara terinfeksi gonore. Terjadi penurunan penderita infeksi gonore sebesar 1.91 juta selama 4 tahun di wilayah ini.

\section{Prevalensi Klamidia di Dunia}

Dari data grafik 3 di bawah ini diamati bahwa prevalensi infeksi klamidia di dunia pada tahun 1995 berjumlah 89.15 juta penduduk dunia. 4 tahun kemudian, di tahun 1999 prevalensi penduduk yang menderita infeksi klamidia berjumlah 91.96 juta dari 120.8 juta penduduk yang menderita STI. Itu berarti lebih dari tiga per empat penderita STI disebabkan oleh infeksi kuman C.trachomatis. Wilayah Asia Selatan dan Asia Tenggara merupakan wilayah dengan infeksi klamidia tertinggi dengan 40.48 juta dan 42.89 juta berturut-turut di tahun 1995 dan 1999. Khuhus di tahun 1999, ada $4.49 \%$ dari 955 juta penduduk di Asia selatan dan Asia tenggara terinfeksi klamidia Terjadi peningkatan penderita infeksi klamidia selang 4 tahun sebesar 2.41 juta penduduk di wilayah ini.

\section{Statistik Gonore dan Klamidia pada 11 area penelitian di Indonesia}

Belum adanya lembaga khusus yang mendata prevalensi PMS di Indonesia agaknya mendatangkan kesulitan tersendiri dalam mendata PMS bagi penulis. Namun demikian, data mengenai IndonesiaPMS khususnya dikarenakan gonore dan infeksi klamidia diperoleh dari hasil penelitian-penelitian para ilmuwan yang concern di bidang ini. Data yang diolah menghasilkan data seperti yang tercantum pada tabel 1 .

\begin{tabular}{|c|c|c|c|}
\hline Lokasi Penelitian & $\begin{array}{l}\text { total } \\
\text { sampel } \\
\text { WPS }\end{array}$ & gonore & $\begin{array}{l}\text { infeksi } \\
\text { klamidia }\end{array}$ \\
\hline Sulawesi Utara, Bitung & 250 & 58 & 60 \\
\hline Jawa Timur, Surabaya & 200 & 62 & 44 \\
\hline Papua, Timika & 114 & 39 & 40 \\
\hline DKI, Jakarta & 203 & 60 & 80 \\
\hline NTT, Kupang & 288 & 89 & 69 \\
\hline Papua, Jayapura & 250 & 54 & 53 \\
\hline Jawa Timur, Banyuwangi & 250 & 90 & 46 \\
\hline Sumatera Utara, Medan & 250 & 74 & 105 \\
\hline Jawa Tengah, Semarang & 250 & 75 & 57 \\
\hline $\begin{array}{l}\text { Sumatera Selatan, } \\
\text { Palembang }\end{array}$ & 250 & 90 & 73 \\
\hline Kep. Riau, T.Pinang & 250 & 77 & 81 \\
\hline
\end{tabular}

Tabel 1. Prevalensi infeksi gonore dan klamidia pada 11 daerah penelitian di Indonesia

Sampel yang diteliti diambil hanya dari ada 2555 jiwa. Dari jumlah sampel ini, total penderita infeksi gonore ada 768 jiwa dan total penderita infeksi klamidia ada 708 jiwa. Prosentase infeksi gonore mencapai 30\% dari 2555 jiwa dan infeksi klamidia 28\% dari 2555 jiwa. Dari data tabel 1 bila dirata-ratakan, maka ada 1 diantara 3 WPS menderita infeksi gonore dan ada 1 diantara 4 WPS menderita infeksi klamidia. Penderita yang terinfeksi gonore lebih banyak 60 sampel dibandingkan yang menderita infeksi klamidia. Adanya kemungkinan di Indonesia bahwa rata-rata, infeksi gonore berkembang dan menyerang kelompok resiko tinggi lebih besar dibandingkan dengan infeksi klamidia. Namun hal ini perlu penelitian lanjut karena pada 5 dari 11 area penelitian menunjukkan bahwa justru infeksi klamidia lebih banyak berdampak pada kelompok resiko tinggi.

\section{Statistik Gonore dan Klamidia di Manado, Sulawesi Utara}

Tabel 2 menunjukkan kelompok resiko tinggi yang terinfeksi Gonore dan Klamidia di kota 
Manado yang angka infeksinya cenderung sama dengan 11 area lain di Indonesia. Tabel di atas kemudian di buat dalam bentuk grafik untuk menunjukkan prosentase di kota Manado antara keduanya.

Tabel 2. Gonore dan Klamidia di Kota Manado

\begin{tabular}{|c|c|c|c|}
\hline Lokasi & $\begin{array}{c}\text { Total } \\
\text { sampel } \\
\text { WTS }\end{array}$ & Gonore & Klamidia \\
\hline Manado 1 & 217 & 23 & 58 \\
Manado 2 & 204 & 40 & 47 \\
\hline
\end{tabular}

Dari data tabel 2 dibuat suatu prosentase mengenai infeksi gonore dan klamidia. Prosentase Gonore di Manado 1 11\% dan Manado 2 20\%. Dan infeksi klamidia dengan prosentase $27 \%$ dan $23 \%$. Meski demikian, total infeksi gonore dan klamidia pada manado 1 yaitu 81 dari 217 orang dan manado 2 yaitu 87 dari 204 objek penelitian. Itu berarti, besar prosentase infeksi gonore dan klamidia di manado 1 yaitu 37.3\% dan manado 2 yaitu $42.6 \%$.

\section{KESIMPULAN} bahwa:

Dari hasil penelitian ini dapat disimpulkan

1. $2.84 \%$ dari 955 juta penduduk di wilayah Asia Selatan dan Asia Tenggara terinfeksi gonore dan 4.49\% dari 955 juta penduduk di Asia selatan dan Asia tenggara terinfeksi klamidia.

2. Pada 11 area penelitian di dalam wilayah negara Indonesia, Prosentase infeksi gonore mencapai 30\% dari 2555 kelompok resiko tinggi dan infeksi klamidia 28\% dari 2555 kelompok resiko tinggi.

3. Kota Manado ternyata memiliki total prosentase infeksi Gonore dan Klamidia berturut-turut $15 \%$ dan $25 \%$ dari 421 kelompok resiko tinggi yang diteliti.

\section{DAFTAR PUSTAKA}

1. Daili SF. Tinjauan Infeksi Menular Seksual (I.M.S). Dalam : Djuanda A. Hamzah M. Aisah S. Ilmu Penyakit Kulit dan Kelamin. Edisi Keenam. Badan Penerbit FKUI, Jakarta, $2010: 363-5$

2. Josodiwondo S. Kokus negatif gram. Dalam : Buku Ajar Mikrobiologi Kedokteran. Edisi revisi. Badan penerbit FKUI, Jakarta, 1994 : 143
3. Josodiwondo S. Chlamydia. Dalam : Buku Ajar Mikrobiologi Kedokteran. Edisi revisi. Badan penerbit FKUI, Jakarta, 1994 : 229

4. World Health Organization. Global Prevalence and Incidence of Selected Curable Sexually Transmitted Infections: Overview and Estimates. Geneva: WHO; 2001.

5. Jazan S. Prevalensi Infeksi Saluran Reproduksi pada Wanita Penjaja Seks di Bitung, Indonesia, 2003.

6. Mawu OF, et.al. Sexually Transmissible Infections Among Female Sex Workers in Manado, Indonesia, Using Multiplex Polymerase Chain Reaction-Based Reverse Line Blot Assay. The Jurnal of Sexual health, 2011, 8, 52-60.

7. Jazan S, dkk. Prevalensi Infeksi Saluran Reproduksi pada Wanita Penjaja Seks di Jayapura, Banyuwangi, Semarang, Medan, Palembang, Tanjung Pinang, dan Bitung, Indonesia, 2003.

8. Clutterbuck D. Sexually Transmitted Infections and HIV. Edisi Pertama. Edinburgh : Elsevier Mosby, 2004.

9. Tanudyaya FK, et al. Prevalence of sexually transmitted infections and sexual risk behavior among female sex workers in nine provinces in Indonesia. Southeast Asian J Trop Med Public Health, 2010; 41: 463-73.

10. Bollen LUM, et al. Addressing The High Prevalence of Gonorrhoea and Chlamydia Among Female Sex Workers in Indonesia: The Results of an Enhanced, Comprehensive Intervention. Sex Transm Infect, 2010; 86: 61-5.

11. Rosana $\mathrm{Y}$, dkk. Studi Resistensi N.gonorrhoeae yang Diisolasi dari Pekerja Seks Komersial Beberapa Tempat di Jakarta (Antimicrobial Susceptibility Patter of N. gonorrhoeae Isolated from Female Commercial Sex Workers in Jakarta). Jurnal Mikrobiologi Indonesia, 1999; 4:2, 60-63.

12. Hartadi. Prospek Penyakit Menular Seksual di Indonesia dalam Kaitannya dengan Era Globalisasi. Dalam : Pidato Pengukuhan Guru Besar Tetap Fakultas Kedokteran Universitas Diponegoro, 1992. 